\title{
Polymorphism of Block3 Region of Merozoite Surface Protein-2 Gene and Multiplicity of Infection in Plasmodium Falciparum in Urban and Rural Settings of Adama and Its Surroundings, Oromia, Ethiopia.
}

Temesgen File ( $\square$ temesgenfile@gmail.com )

Adama Science and Technology University https://orcid.org/0000-0003-2126-5617

Hunduma Dinka

Adama Science and Technology University

Lemu Golassa

Addis Ababa University, Akililu Lemma Institute of Pathobiology

Research

Keywords: Polymorphism, msp-2, Multiplicity of infection, Expected heterozygosity, P. falciparum

Posted Date: August 14th, 2021

DOI: https://doi.org/10.21203/rs.3.rs-798934/v1

License: (1) (i) This work is licensed under a Creative Commons Attribution 4.0 International License.

Read Full License 


\section{Abstract}

Background: Despite significant progress achieved globally in reducing malaria burden, still it is one of the major public health problems in Ethiopia. Furthermore, better understanding of genetic polymorphism of $\mathrm{P}$. falciparum: the most virulent and predominant malaria parasite primarily targeted in malaria control and elimination program is paramount. Analysis of block 3 region of msp- 2 gene of P. falciparum provides strong molecular evidence to evaluate the real picture of malaria epidemiology to fine-tune the ongoing control and elimination programs in the region. Thus, this study aimed to examine the status of such polymorphic gene and its implications in Adama and its surrounding.

Methods: A total of 171 Dry Blood Spot (DBS) samples were collected from uncomplicated falciparum malaria patients from September 2019 to August 2020. Tween ${ }^{\circledR} 20$ and Chelex method was employed for parasite DNA extraction. A total of 148 samples were successfully amplified by nested PCR targeting msp-2 alleles (IC/3D7 and FC27) followed by gel electrophoresis for fragment analysis.

Results: Seventeen different polymorphic forms of msp-2 allelic fragments were detected in the study area. Moreover, a total of $47(31.8 \%)$ and $41(27.7 \%)$ were detected for IC/3D7 and FC27 allelic family, respectively. Furthermore, the multi-clonal allele type accounted for $60(40.5 \%)$. The overall MOI was 1.4 and the expected heterozygosity is 0.49 indicating nearly intermediate malaria transmission in the study area.

Conclusions: The study revealed nearly intermediate genetic diversity and polyclonal infection of $P$. falciparum in the study area, demanding further scale up of the ongoing control and elimination efforts.

\section{Background}

World Health Organization (WHO) report shows that; in 2019, the number of malaria cases were 229 million, out of which 409,000 deaths was recorded. More than $90 \%$ of all malaria cases and death were only from sub-Saharan Africa (SSA) [1]. About $68 \%$ of Ethiopian population is residing in malarious area. $P$. vivax and $P$. falciparum are the two co-endemic species in the country, sharing the overall burden of 30 and $70 \%$, respectively [2, 3]. In Ethiopia, even though malaria is responsible for a major public health problem, the various intervention efforts made so far has significantly reduced the disease burden. This successes have promoted the country to move forward and plan for malaria elimination strategies in selected areas [4]. However, the major hurdle that limited the national effort to combat malaria in Ethiopia are; the challenges related to effective implementation of major intervention strategies for malaria control like early diagnosis, prompt treatment, selective vector control, environmental management, and resource intensive nature of the programs $[4,5]$. In addition, studies also show that a number of factors like, the emergence of insecticide resistance by the mosquito vectors, increased population density, global warming, poverty, the lack of effective vaccines, the emergence and spread of drug resistant strains could limit malaria control and elimination plan [6, 7]. Added to this, the frequent emergence and spread of genetic diversity of the predominant malaria parasite, $P$. falciparum, is another challenge. 
.In malaria endemic region, $P$. falciparum infection is characterized by having higher genetic diversity, which is implicated in its evolutionary fitness, and consequently having more survival advantage by overcoming the control efforts [8]. Genetic diversity is also an indicator of the intensity of transmission [9], and potential deficiencies in malaria control programs [10]. The most commonly used techniques for molecular characterization of such polymorphism in malaria infection is the nested amplification of merozoite surface proteins ( $\mathrm{msp}$ ) like block 3 region of $\mathrm{msp}-2$ gene $[11,20]$. msp2 is a glycoprotein approximately $30 \mathrm{kDa}$ encoded by the msp2 gene located on chromosome 2 . It is composed by five blocks of which the central block (block 3 ) is the most polymorphic [12,13]. Msp-2 is a highly polymorphic antigenic marker that has been used extensively to describe the parasite populations, thus used as a discriminatory and informative marker for strain differentiation [6]. Due to the variable nonrepeat sequences as well as the varying sizes of the tandem repeats in the central region, msp2 gene is a dimorphic and existing in two main allelic families; FC27 and ICI/3D7 [14, 20]. Therefore, molecular based investigation of the diversity of $P$. falciparum and its multiplicity of infection (MOI) could be used to describe the level of malaria transmission in a given locality. For successful malaria elimination, information on the genetic profile of the parasite population in different geographical area, and factors that determine gene flow between locations is paramount. Even though, genetic diversity of $P$. falciparum has been extensively studied in different part of the world, limited and mainly a single health facility based molecular data were yet available only from, southwestern, northwestern and northeastern part of Ethiopia.

The aim of this study was, to examine genetic polymorphism of block 3 region of msp-2 gene of $P$. falciparum and its multiplicity of infection (MOI) from three districts around Adama, including Adama town administration.

\section{Materials And Methods \\ 2.1 Study sites}

The study was carried out in three districts of central Ethiopia (Adama, Modjo, and Olanciti), including Adama town administration. Blood sample collection for DBS preparation and relevant patient data from malaria patient due to $P$. falciparum was collected from September 2019 to August 2020. The sites included in the study area were mainly from Adama town. The remaining were from; Adama district including Wonji located at $8 \mathrm{~km}$ south of Adama and Awash Malkasa situated at a distance of $15 \mathrm{~km}$ southeast of Adama and other health facilities located in neighboring districts like Modjo located at 16 $\mathrm{km}$ northwest of Adama and Olanciti situated at 23km northeast of Adama (Fig. 1). Adama is the major town next to the main capital in central Ethiopia, located at a distance of about $99 \mathrm{~km}$ southeast of Addis Ababa. Similar to the other part of the country where malaria is endemic, malaria transmission in study area is seasonal based on the rainfall patterns that is heavy from mid -June to mid-September which accounts for major malaria transmission season from mid-September to December. And shorter rainy period near April resulting minor malaria transmission until June [15]. According to the 2007 projection of Loading [MathJax]/jax/output/CommonHTML/jax.js the study area estimated to reach 800,000 inhabitants. 
Adama and its neighboring districts are located in the Rift Valley region of central Ethiopia (Fig. 1), where malaria is endemic. The major factors contributed for such malaria endemicity are topographic location less than $\mathbf{2 0 0 0}$ meter above sea level, seasonality of rainfall pattern. In addition, average annual temperature that ranges from $16-32^{\circ} \mathrm{C}$ suitable for the breeding of Anopheles arabiensis (the predominant malaria vector in the region), and various micro ecological factors that favor mosquito breeding $[15,16]$.

Figure 1: Map of the study area

\subsection{Sample collection and processing}

A total of 171 microscopically confirmed $P$. falciparum infected patient data and blood samples were collected (aged 1 to 66) from selected health facilities in Adama, Modjo, Wonji, Awash Malkasa and Olanciti towns. Health facilities were purposively selected based on physical location and history of patient caseload. P. falciparum positive blood samples for Dry Blood Spot (DBS) preparation by spotting it on Whatman ${ }^{\mathrm{TM}} 3 \mathrm{MM}$ filter paper and patient data were collected from all study sites from September 2019 to August 2020. The inclusion criteria for this study was uncomplicated malaria cases due to $P$. falciparum, having history of fever onset since 24 hours of the clinical examination. For the sample and patient data collection, experienced medical laboratory technologist were selected. The recruited laboratory professionals trained to conduct finger prick and collect blood sample with patient data. For malaria microscopy, thick and thin blood films prepared, air-dried and stained with 10\% Giemsa for 15 minutes. At least two independent laboratory technologist identified malaria parasite species and counted the parasitaemia level. When the sexual form (gametocytes) seen, the slide was excluded from the count. Slide considered positive after two concordant readings by two different microscopists. When discrepancy occurred, the third microscopist made the decision.

The number of parasite density per microliter $(\mu \mathrm{l})$ of blood was calculated by using the following formula: Parasite Density per microliter $(\mu \mathrm{l})$ of blood $=$ Number of Parasite counted $x\left(\frac{8000}{200}\right),[17,18]$. Assuming that X number parasite was counted per 200 WBC in thick film, and about 8000 WBC is expected to be present in $1 \mu$ l of blood.

For comparison with ranked order variables during data analysis, parasitemia were categorized in to five levels: L1 (< 50 parasite/ $\mu$ l blood), L2 (50-499 parasite / $\mu$ blood), L3 (500-4999 parasite / $\mu$ l blood), L4 (5000-49999 parasite/ $\mu$ blood), and L5 ( $\geq 50,000$ parasite/ $\mu$ l blood) [19].

\subsection{Extraction of $P$. falciparum DNA and amplification of msp-2 gene}

The parasite genomic DNA extraction and its msp-2 gene amplification was conducted at malaria research laboratory, Akililu Lemma Institute of Pathobiology, Addis Ababa University (AAU). The extraction of aenomic DNA of $P$. falcinarum from the spotted Whatman 3MM filter paper was carried out Loading [MathJax]/jax/output/CommonHTML/jax.js 
by using $0.5 \%$ Tween ${ }^{\circledR} 20$ (Sigma-Aldrich, USA) to lyse RBC, tracked by treatment with $6 \%$ chelex $\circledast 100$ (Sigma-Aldrich, USA) in water bath at $96^{\circ} \mathrm{C}[20]$.

The polymorphic region of $P$. falciparum msp-2 gene (block 3) was used as a genetic marker for the genotyping of parasite populations.

Nested PCR of msp-2 (block 3) polymorphic region was performed by slight modification of primers and methods from the previously described reports $[20,21]$ (S1-Table). In brief, initial amplification (N1) of msp-2 gene were carried out in a final volume of $20 \mu \mathrm{l}$ amplification mixture containing $0.5 \mu$ l of each primer, 5x FIREPol ${ }^{\circledR}$.Master Mix (MM), $11 \mu \mathrm{l}$ of nuclease free water aliquot to $16 \mu$ l to which $4 \mu \mathrm{l}$ of DNA template was added. In the second (N2) amplification reaction, $2 \mu \mathrm{l}$ of the amplicon product was used. The PCR amplification profile for both N1 and N2 reactions includes; initial denaturation at $95^{\circ} \mathrm{C}$ for 3 minutes, denaturation at $94^{\circ} \mathrm{C}$ for 1 minute, annealing $58^{\circ} \mathrm{C}$ for 1 minute, elongation at $72^{\circ} \mathrm{C}$ for 2 minutes and final elongation for 5 minutes. Allele specific positive control 3D7 and DNA free negative control were used in each set of the reactions as described elsewhere. Gel-electrophoresis of DNA fragment for msp-2 allelic families were performed on $2 \%$ agarose gel stained with ethidium bromide and visualized under Benchtop 2UV trans-illuminator (UVP), USA and photographed to estimate band size in relation to 50bp DNA ladder (Invitrogen, by thermal Fisher-scientific) (S2-Figure). The detection of one PCR fragment on each locus indicates infection is monoclonal, whereas the presence of more than one fragment on each locus shows polyclonal infection [22]. When the size of allele fragment was found less than $20 \mathrm{bp}$ interval they were considered the same [23].

\subsection{Data Analysis}

Descriptive statistics was used to calculate the frequencyof each msp-2 allelic families in relation to the total number of gene successfully amplified for that locus. Multiplicity of Infection (MOI) for $P$. falciparum calculated as total number of parasite genotypes for the same gene and the number of PCR positive isolates. Size polymorphism in each allelic family shows that one band represents one amplified PCR fragment derived from a single copy of $P$. falciparum msp-2 gene. When alleles in each family was less than $20 \mathrm{bp}$, they considered the same.

Pearson Chi square test was conducted for statistical comparison of categorical variables. $P<0.05$ was used to test the level of statistical significance to accept or reject the hypothesis. All statistical tests were performed by using SPSS version 20.0 (SPSS Inc., Chicago, USA.

The expected heterogeneity $(\mathrm{He})$ was calculated by the formula;

$$
H e=\left(\frac{n}{n-1}\right)\left(1-? p^{2}\right)
$$

Where $\mathrm{n}$ is, the number of the isolates analyzed and $\mathrm{p}$ represents the frequency of each different allele at 


\subsection{Ethical Consideration}

\section{Ethical approval}

of the study obtained from Institutional Ethical Review Board of Adama Science and Technology University (ASTU). Oromia Regional State Health Bureau, approved and gave consent for the study protocol. In addition, written informed consent obtained from the patients or their parents/guardian prior to recruitment.

\section{Results}

\subsection{Demographic and parasitological data}

From 171 microscopically confirmed malaria patients due to $P$. falciparum, 148 samples successfully amplified for msp-2 gene. Of which 105 (71\%) were males. The age of the study participant ranged from 1 to 66 . Mean \pm SD $\left(27.0 \pm 13.6^{*}\right)$ years. Asexual parasite density ranged from $64-104,320$ parasites/ $\mu \mathrm{l}$ with a geometric mean of 5,654 parasites/ $\mu$ l. Of all study participants $85(57 \%)$ were from urban inhabitants. Of all the study subjects by occupation, students, daily laborers and farmers alone accounted for $113(76 \%)$ P. falciparum malaria cases in the study area. Moreover, the incidence of $P$. falciparum isolates were having significant relation $\left(\mathbf{X}^{2}=0.017\right)$ with occupation type (Table 1$)$. 
Table 1

Socio-demographic characteristics and parasitological data of symptomatic malaria patients due to $P$. falciparum clinical isolates genotyped for msp-2 gene from Adama and its surroundings $(n=148)$.

\begin{tabular}{|c|c|c|}
\hline Patient characteristics & Sample genotyped & Chi square $\left(X^{2}\right)$ \\
\hline Mean age (year) & $27.0 \pm 13.6 *(S D)$ & \\
\hline Age range (year) & $1-66$ & 0.09 \\
\hline Sex ratio (Male/Female) & $105 / 43$ & 0.18 \\
\hline Residence (Urban/ Rural) & $85 / 63$ & 0.56 \\
\hline \multicolumn{3}{|l|}{ Occupation } \\
\hline Farmer & $31(21 \%)$ & \multirow[t]{7}{*}{0.017} \\
\hline Housewife & $12(\%)$ & \\
\hline Daily laborer & $35(23.8 \%)$ & \\
\hline Government employee & $13(8.8 \%)$ & \\
\hline NGO employee & $2(1.3 \%)$ & \\
\hline Business man & $7(4.7 \%)$ & \\
\hline Student & $47(32 \%)$ & \\
\hline Geometric mean of parasitic density $(\mathrm{P} / \mu \mathrm{l})$ of blood & 5,654 & \\
\hline Parasite density range $(\mathrm{P} / \mu \mathrm{l})$ of blood & $64-104,320$ & \\
\hline $\begin{array}{l}\text { Parasitaemia level } \\
-(50-499 \mathrm{P} / \mu \mathrm{l} \text { of blood })\end{array}$ & $5(3.3 \%)$ & \multirow[t]{4}{*}{0.075} \\
\hline - (500-4999 P/ $\mu \mathrm{l}$ of blood) & $63(42 \%)$ & \\
\hline - $(5000-49,999 \mathrm{P} / \mu \mathrm{l}$ of blood) & $75(50.6 \%)$ & \\
\hline - $(\geq 50,000 \mathrm{P} / \mu \mathrm{l}$ of blood $)$ & $5(3.3 \%)$ & \\
\hline
\end{tabular}

\subsection{Allele frequency, genetic diversity and multiplicity of infection}

Allele genotyping of msp-2 gene of $P$. falciparum in Adama and its surroundings revealed its polymorphic nature. The frequency of IC/3D7 and FC27 was 31.8\% (47/148) and 27.7\% (41/148), respectively. Moreover, 40.5\% (60/148) carried both IC/3D7 and FC27 alleles, with the overall MOI of 1.4 and the expected heterozygosity $(\mathrm{He})$ of 0.49 . 
In addition, size polymorphism demonstrated in the study revealed that 106 and 99 samples were successfully genotyped for IC/3D7 and FC27 variant forms, respectively. In this study among the msp-2 isolates: we observed seven IC/3D7 (200-700bp) and ten FC27 (250-700bp) different size polymorphic alleles (Table 2).

Table 2

Genetic diversity, allelic frequency and allelic fragment size of block 3 region of msp-2 gene isolated from symptomatic patients in Adama and its surroundings, Oromia, Ethiopia $(n=148)$.

\begin{tabular}{|c|c|c|c|c|c|}
\hline $\begin{array}{l}\text { Msp-2 alleles ( } n \\
=148)\end{array}$ & $\begin{array}{l}\text { Allele } \\
\text { frequency } \\
n(\%)\end{array}$ & $\begin{array}{l}\text { Fragment size } \\
\text { (bp) }\end{array}$ & $\begin{array}{l}\text { Number of } \\
\text { alleles }\end{array}$ & $\begin{array}{l}\text { Overall } \\
\text { MOI }\end{array}$ & $\begin{array}{l}\text { Expected } \\
\text { Heterozygosity }(\mathrm{He})\end{array}$ \\
\hline IC/3D7 & 47 (31.8) & $200-700$ & 7 & \multirow[t]{4}{*}{1.4} & \multirow[t]{4}{*}{0.49} \\
\hline $\mathrm{FC} 27$ & $41(27.7)$ & $250-700$ & 10 & & \\
\hline $3 D 7+I C / 3 D 7$ & $60(40.5)$ & & & & \\
\hline Total & 148 & & & & \\
\hline
\end{tabular}

Comparison of geometric mean of the parasite density at different age group shown disproportionate burden of parasitemia in school age children (SAC). The overall rate of clinical prevalence of msp-2 gene allelic variant among symptomatic patients tends to increase with age groups, although the variation was not statistically significant $\left(X^{2}=0.09\right)$. Likewise, though not linearly $\mathrm{MOI}$ slightly risen up with age group (Table 3).

Table 3

Distribution of msp-2 allelic variants, average $\mathrm{MOI}$, and geometric mean of parasite density among different age groups of $P$. falciparum infection in Adama and its surroundings.

\begin{tabular}{|llllll|}
\hline Characteristics & \multicolumn{5}{l}{ Age groups in year } \\
& $\mathrm{n}(\%)$ & $\mathrm{n}(\%)$ & $\mathrm{n}(\%)$ & $\mathrm{n}(\%)$ & $\mathrm{n}(\%)$ \\
\hline ICI/3D7 & $2(4.2)$ & $4(8.5)$ & $10(21)$ & $31(66)$ & 47 \\
\hline FC27 & $2(4.8)$ & $7(17)$ & $14(34)$ & $18(44)$ & 41 \\
\hline ICI/3D7 + FC27 & $1(1.7)$ & $6(10)$ & $28(47)$ & $25(41.7)$ & 60 \\
\hline Total & $5(3.4)$ & $17(11)$ & $52(35)$ & $74(50)$ & 148 \\
\hline Average MOI & 1.25 & 1.54 & 2.1 & 1.5 & \\
\hline Geometric mean of parasite density & 6455 & 7419 & 4324 & 6381 & \\
\hline
\end{tabular}

Analysis of the urban rural distribution of msp-2 allelic families in Adama and its surrounding shown no pinnifinnnt unrintinn of allolin wnrinntn in urhan and rural localities $(P=0.56)$. However, as revealed in Loading [MathJax]/jax/output/CommonHTML/jax.js 
(Fig. 2) msp-2 allelic family in study area revealed similarity, except higher $\mathrm{MOI}$ in school age children from urban localities compared with similar age groups from rural area.

Figure 2. Urban rural features in $\mathrm{MOI}$ of $P$. falciparum msp-2 allelic families isolated from different age groups of symptomatic patients in Adama and its surroundings, Oromia, Ethiopia $(n=148)$.

On the other hand, the distribution of msp-2 allelic variant in different study sample collection sites indicated a highly significant variation $(p=0.00)$ (Fig. 3).

Figure 3. The distribution of $P$. falciparum msp-2 allelic families isolated from different sample collection sites from symptomatic patients in Adama and its surroundings, Oromia, Ethiopia $(n=148)$.

Moreover, the distribution of msp-2 allelic variants detected in the study area showed slight variation during major malaria season and relatively stable during minor malaria season (Fig. 4).

Figure 4. The distribution of $P$. falciparum msp-2 allelic families clinically isolated during major and minor malaria season from symptomatic patients in Adama and its surroundings, Oromia, Ethiopia $(n=148)$.

\section{Discussion}

Ethiopia has now moved forward in targeting nationwide malaria elimination program by 2030 . For effective implementation of this strategic target, one of the key intervention strategy is improving malaria surveillance and response [24]. In this regards, molecular epidemiological study approach like characterization of block 3 region of $P$. falciparum msp-2 provides comprehensive molecular evidence for effective disease surveillance that ultimately transformed to core interventions to the control and elimination of malaria.

The present study revealed that consistence with our previous report [25] and that of [15], incidence of $P$. falciparum isolates was higher in male (71\%) individuals (Table 1 ). The major factors that may account for such higher malaria cases compared to female is that older boys and men may be at special risk for malaria from occupational and travel-related factors [24]. In addition, consistent with the report of [26] incidence of $P$. falciparum isolates in the present study was significantly related to occupation type $\left(\mathbf{X}^{2}=\right.$ 0.017) (Table 1). This could be due to strong relation of malaria incidence with lower standard of living. This might have contributed for the occurrence of $76 \%$ of all $P$. falciparum isolates in the present study only from farmers, daily laborers, and students alone.

Investigation of msp-2 block-3 region of $P$. falciparum genetic profile revealed in this study was the first in its kind in our study area. Moreover, we examined the seasonal and spatial distribution of msp-2 allelic variants in selected sites within the designated study area, together with their urban rural counterpart. Of the total successfully genotyped msp-2 gene the monoclonal alleles of IC/3D7 and FC27 constitute $31.8 \%$ and $27.7 \%$ respectively (Table 2). Report from maritime region of Togo [27] and Ponte-Noire, Republic of Congo) [28] complement our finding. Moreover, the number of msp-2 genotypes detected for Loading [MathJax]/jax/output/CommonHTML/jax.js 
IC/3D7 and FC27 was 7 and 10 respectively (Table 2). Although the number of genotypes might have be underestimated due to the limitation of the techniques. Fragment size polymorphism described in this study is nearly comparable with the previous report from Republic of Congo [28], Nigeria [29], Sudan [17], and northeastern Ethiopia [30]. Other reports from Congo Brazzaville [31], north western Ethiopia [32] shown the predominance of IC/3D7 allelic family. Such inconsistency in $P$. falciparum allelic size polymorphism could be due to geographical location, transmission intensity and scope of sample population covered in the study. The rate of msp-2 polyclonal infection identified was $40.5 \%$, with the overall MOI of 1.4 (Table 2). This finding is lower than the previous report from southwestern Ethiopia [33] northwesten Ethiopia [32], Sudan [17], Cameroon [34], and Nigeria [35]. And somewhat higher than the previous report from north eastern Ethiopia [30], and Ghana [36]. The variation in multi-clonal infection and multiplicity of infection could be due to the overall prevalence of infection in the population and the age of the individual [37]. The overall MOI identified in our study area could serve as proxy of transmission intensity for targeted intervention in the region. Moreover, in the present study we investigated the expected heterozygosity $(\mathrm{He})$ of 0.49 (Table 2 ) that nearly indicates an intermediate transmission pattern in the study area.

In this study, analysis of the variation of msp-2 allelic frequency across different age groups generally tends to rose up with age group in parallel with $P$. falciparum clinical prevalence during the study period. However, the variation was not statistically significant $(P=0.09)$ (Table 3$)$. The general increment observed in this study is in agreement with the previous five year retrospective study reported in Adama, where the clinical cases of $P$. falciparum rose up with age group [16]. In the present study, we found that $\mathrm{MOI}$ tends to increase with age groups until the age of late adolescent (Table 3 ). This finding differ from the report from hyper endemic area of Burkina Faso [38], where they reported the existence of negative relationship between $\mathrm{MOI}$ with patient age. On the other hand, consistent with our finding other report from Burkina Faso [37], and Tanzania [39], explained that episode of infection in children is commonly for very short duration and the duration of episode of infection increases with age contributing to the rise in $\mathrm{MOI}$ in other age groups. When the correlation of msp-2 allelic variant and parasitemia level was examined, we found no statistically significant correlation (Pearson correlation $=-0.19, X^{2}=0.07$ ) existed between msp-2 allelic variants with parasitemia level in different age groups (Table 3). This could be due to the reduced transmission intensity of $P$. falciparum infection in the study area. Even though different factors may contribute to the fluctuation of parasitaemia level in symptomatic patients over time, the highest geometric mean of microscopically detected parasitemia level was in school age children (5-14 years old) (Table 3). This was due to delayed acquisition of protective immunity of this age groups [40].

Unlike the report from Burkina Faso, where there was a difference in some allelic family observed in rural and urban settings probably due to urbanization [37], in the present study, we observed no statistically significant variation in both rural and urban localities $(P=0.56)$. This indicates the existence of similar malaria epidemiology in both rural and urban settings of the study area. Slightly higher $\mathrm{MOI}$ detected school age children (Fig. 2) could be due to higher (70\%) malaria case due to $P$. falciparum of this age group from urban area. Moreover, study site based distribution of msp-2 allelic variant (Fig. 3) showed a 
highly significant variation $(P=0.000)$. This could be largely due to the differences in local microecological factors that may result in varying mosquito population density, change in parasite vector interaction, change in host immunity induced by parasite interaction, and spatial heterogeneity of the study sites under consideration [41, 42]. These major factors might have affected local transmission pattern contributing to such variation. In Ethiopia there are two malaria season. The major season follow the rainy summer season from June to August that begins from September to December. The minor malaria season follow the shorter rainy season around April and May (FMOH, 2015). Analysis of intra seasonal variation on the distribution of msp-2 allelic variant (Fig. 4) showed relatively higher variation during major malaria season, although the variation is not statistically significant $(p=0.9)$. In complement with this finding [37] reported that the dominance of any msp-2 allele was dependent on transmission intensity and independent of seasonal change.

\section{Conclusions}

The present molecular study revealed nearly moderate transmission of $P$. falciparum clinical isolates among symptomatic malaria patients: having polyclonal infection rate of (40.5), $\mathrm{MOI}(1.4)$ and $\mathrm{He}(0.49)$ in such malaria endemic region of central Ethiopia. Therefore, to sustain such declining phase of malaria transmission, in addition to the classical epidemiological study approach: the ongoing malaria control and elimination program should be accompanied with similar molecular surveillance for targeted intervention. Moreover, the present study revealed absence of significant variation in allele frequency in both urban and its rural counterpart and similar allele frequency during the major and minor malaria season, reflecting frequent inbreeding among the existing parasite strains in both settings. This implicates the presence of similar malaria epidemiology demanding similar intervention in both urban and rural areas during the major and minor malaria season in the study area. Thus, the findings described in this study, will serve as a baseline molecular evidence for further research on areas having similar malaria epidemiology to make the control and elimination efforts effective.

\section{Abbreviations}

Bp: Base pair; msp-1: Merozoite surface protein-2; MOI: Multiplicity of infection; PCR: Polymerase chain reaction; SAC: School age children.

\section{Declarations}

\section{Ethics approval and consent to participate}

The research and ethical committee of Adama Science and Technology University reviewed and approved the study protocol, as verified through certificate reference number RECSoANS/BIO/01/2019. Oromia Health Bureau also approved the study protocol. 
- Not applicable

\section{Availability of data and materials}

All relevant data is included in manuscript, and the datasets analyzed in the study are available from the corresponding author on reasonable request. Additional data uploaded with main document.

\section{Competing interests}

- The authors declare that they have no competing of interest

\section{Funding}

- No funding was obtained for this study

\section{Authors' contributions}

TF designed, conducted and analyzed the study, drafted and wrote the manuscript. HD designed the study and finally reviewed and approved the manuscript. LG conceived the idea, designed the study, supervised the molecular laboratory work, and reviewed and approved the manuscript.

\section{Acknowledgements}

We thank data collectors from all health facilities in the study area. We are grateful to all study participants, parents and guardian for the children who participated in the study. We strongly acknowledge Oromia Health Bureau and Adama regional laboratory for their consent and support in data collection and storage from the selected health facilities in the study area. We also thank Mr. Ahimed Tola (Geomatics Engineer) for his kind assistance in sketching map of study areas by using Arc-GIS Desktop version 10.4 .

\section{Authors' Information}

${ }^{1}$ Department of Applied Biology, Adama Science and Technology University, P.O.Box 1888, Adama, Ethiopia. ${ }^{2}$ Aklilu Lemma Institute of Pathobiology, Addis Ababa University, P.O.Box 1176, Addis Ababa, Ethiopia.

\section{References}

1. WHO. World Malaria Report 2020. World Health Organization. 2020.

2. "U. S. President 's malaria initiative ETHIOPIA Malaria Operational Plan FY 2020," pp. 1-107, 2020.

3. Solomon A, Kahase D, Alemayehu M. Trend of malaria prevalence in Wolkite health center: An implication towards the elimination of malaria in Ethiopia by 2030. Malar J. 2020;19(1):1-8. doi:10.1186/s12936-020-03182-z. 
4. MOH. "NATIONAL STRATEGIC PLAN FOR MALARIA PREVENTION," vol. 2015, no. August 2010, 2015.

5. Tadesse F, Fogarty AW, Deressa W. "Prevalence and associated risk factors of malaria among adults in East Shewa Zone of Oromia Regional State, Ethiopia : a cross-sectional study," pp. 1-8, 2018, doi: 10.1186/s12889-017-4577-0.

6. Mwingira F, et al. allele frequency and diversity in sub-Saharan Africa. Malar J. 2011;10(1):79. doi:10.1186/1475-2875-10-79.

7. Sonko ST, Jaiteh M, Jafali J, Jarju LBS, Alessandro UD, Camara A. “Does socio-economic status explain the differentials in malaria parasite prevalence ? Evidence from The Gambia," pp. 1-12, 2014.

8. Takala SL, et al., "Malaria: Implications for Vaccine Development," vol. 1, no. 2, pp. 1-21, 2010, doi: 10.1126/scitransImed.3000257.Extreme.

9. Soe TN, et al., "Genetic diversity of Plasmodium falciparum populations in southeast and western Myanmar," pp. 1-6, 2017, doi: 10.1186/s13071-017-2254-x.

10. Mohammed H, Kassa M, Mekete K, Assefa A, Taye G, Commons RJ. Genetic diversity of the msp-1, msp-2, and glurp genes of Plasmodium falciparum isolates in Northwest Ethiopia 11 Medical and Health Sciences 1108 Medical Microbiology. Malar J. 2018;17(1):1-8. doi:10.1186/s12936-0182540-x.

11. Bakhiet AMA, et al. Acta Tropica Plasmodium falciparum population structure in Sudan post artemisinin-based combination therapy. Acta Trop. 2015;148:97-104. doi:10.1016/j.actatropica.2015.04.013.

12. Smythe JA, et al., "Structural diversity in the Plasmodium falciparum merozoite surface antigen 2," vol. 88, no. March, pp. 1751-1755, 1991.

13. Beeson JG, Drew DR, Boyle MJ, Feng G, Fowkes FJI, Richards JS, "Merozoite surface proteins in red blood cell invasion, immunity and vaccines against malaria," FEMS Microbiology Reviews, vol. 40, no. 3. Oxford University Press, pp. 343-372, May 01, 2016, doi: 10.1093/femsre/fuw001.

14. Duah NO, Matrevi SA, Quashie NB, Abuaku B, Koram KA. "Genetic diversity of Plasmodium falciparum isolates from uncomplicated malaria cases in Ghana over a decade," Parasites Vectors, 9, 1, 2016, doi:10.1186/s13071-016-1692-1.

15. Golassa L, White MT. Population-level estimates of the proportion of Plasmodium vivax blood-stage infections attributable to relapses among febrile patients attending Adama Malaria Diagnostic Centre, East Shoa Zone, Oromia, Ethiopia. Malar J. 2017;16(1):1-11. doi:10.1186/s12936-017-19443.

16. File T, Dinka H, Golassa L. "A retrospective analysis on the transmission of Plasmodium falciparum and Plasmodium vivax: The case of Adama City, East Shoa Zone, Oromia, Ethiopia," Malar J, 18, 1, 2019, doi:10.1186/s12936-019-2827-6.

17. Hamid MMahdiA, et al. Multiplicity of infection and genetic diversity of Plasmodium falciparum isolates from patients with uncomplicated and severe malaria in Gezira State, Sudan. Parasites 
18. WHO. "Malaria Parasite Counting. World Health Organization.," pp. 1-5, 2016, [Online]. Available: http://www.wpro.who.int/mvp/lab_quality/2096_oms_gmp_sop_09_rev1.pdf.

19. Diouf $B$, et al. Association of high Plasmodium falciparum parasite densities with polyclonal microscopic infections in asymptomatic children from Toubacouta, Senegal. Malar J. 2019;18(1):18. doi:10.1186/s12936-019-2684-3.

20. Snounou G, Singh B, "Nested PCR analysis of Plasmodium parasites," no. May 2014, 2002, doi: 10.1385/1-59259-271-6.

21. Chen JT, et al. Genetic diversity and allele frequencies of Plasmodium falciparum msp1 and msp2 in parasite isolates from Bioko Island, Equatorial Guinea. Malar J. 2018;17(1):1-9. doi:10.1186/s12936-018-2611-z.

22. Kiwuwa MS, et al. Genetic diversity of Plasmodium falciparum infections in mild and severe malaria of children from Kampala, Uganda. Parasitol Res. 2013;112(4):1691-700. doi:10.1007/s00436-0133325-3.

23. Ogouyèmi-Hounto $A$, et al. Genetic polymorphism of merozoite surface protein-1 and merozoite surface protein-2 in Plasmodium falciparum isolates from children in South of Benin. Parasite. 2013;20(1):1-7. doi:10.1051/parasite/2013039.

24. $\mathrm{MOH}$. “Ethiopia malaria elimination strategic plan: 2021-2025," no. August 2020, pp. 2021-2025, 2021.

25. File T, Dinka H. A preliminary study on urban malaria during the minor transmission season: The case of Adama City, Oromia, Ethiopia. Parasite Epidemiol Control. Nov. 2020;11:e00175. doi:10.1016/j.parepi.2020.e00175.

26. Degarege A, Fennie K, Degarege D, Chennupati S, Madhivanan P. Improving socioeconomic status may reduce the burden of malaria in sub Saharan Africa: A systematic review and meta-analysis. PLoS One. 2019;14(1):1-26. doi:10.1371/journal.pone.0211205.

27. Awaga $\mathrm{KL}$, et al. Genetic diversity and genotype multiplicity of Plasmodium falciparum infections in symptomatic individuals in the maritime region of Togo. Trop Med Int Heal. 2012;17(2):153-60. doi:10.1111/j.1365-3156.2011.02913.x.

28. Singana BP, Mayengue PI, Niama RF, Ndounga M. Genetic diversity of Plasmodium falciparum infection among children with uncomplicated malaria living in Pointe-Noire, Republic of Congo. Pan Afr Med J. 2019;32:183. doi:10.11604/pamj.2019.32.183.15694.

29. Funwei RI, Thomas BN, Falade CO, Ojurongbe O. Extensive diversity in the allelic frequency of Plasmodium falciparum merozoite surface proteins and glutamate-rich protein in rural and urban settings of southwestern Nigeria. Malar J. 2018;17(1):1-8. doi:10.1186/s12936-017-2149-5.

30. Mohammed H, Assefa A, Chernet M, Wuletaw Y, Commons RJ. Genetic polymorphisms of Plasmodium falciparum isolates from Melka-Werer, North East Ethiopia based on the merozoite surface protein-2 (msp-2) gene as a molecular marker. Malar J. 2021;20(1):1-7. doi:10.1186/s12936-021-03625-1. 
31. Mayengue PI, et al. Variation of prevalence of malaria, parasite density and the multiplicity of Plasmodium falciparum infection throughout the year at three different health centers in Brazzaville, Republic of Congo. BMC Infect Dis. 2020;20(1):1-10. doi:10.1186/s12879-020-4913-3.

32. Mohammed H, Kassa M, Assefa A, Tadesse M, Kebede A. Genetic polymorphism of Merozoite Surface Protein-2 (MSP-2) in Plasmodium falciparum isolates from Pawe District, North West Ethiopia. PLoS One. 2017;12(5):1-11. doi:10.1371/journal.pone.0177559.

33. Abamecha A, et al. Genetic diversity and genotype multiplicity of Plasmodium falciparum infection in patients with uncomplicated malaria in Chewaka district, Ethiopia. Malar J. 2020;19(1):1-9. doi:10.1186/s12936-020-03278-6.

34. Metoh TN, Chen JH, Fon-Gah P, Zhou X, Moyou-Somo R, Zhou XN. Genetic diversity of Plasmodium falciparum and genetic profile in children affected by uncomplicated malaria in Cameroon. Malar $\mathrm{J}$. 2020;19(1):1-15. doi:10.1186/s12936-020-03161-4.

35. Oyedeji SI, Bassi PU, Oyedeji SA, Ojurongbe O, Awobode HO. Genetic diversity and complexity of Plasmodium falciparum infections in the microenvironment among siblings of the same household in North-Central Nigeria. Malar J. 2020;19(1):1-10. doi:10.1186/s12936-020-03415-1.

36. Adjah J, Fiadzoe B, Ayanful-Torgby R, Amoah LE. Seasonal variations in Plasmodium falciparum genetic diversity and multiplicity of infection in asymptomatic children living in southern Ghana. BMC Infect Dis. 2018;18(1):1-10. doi:10.1186/s12879-018-3350-z.

37. Soulama I, et al. Plasmodium falciparum genotypes diversity in symptomatic malaria of children living in an urban and a rural setting in burkina Faso. Malar J. 2009;8(1):1-8. doi:10.1186/14752875-8-135.

38. Sondo $P$, et al. Determinants of Plasmodium falciparum multiplicity of infection and genetic diversity in Burkina Faso. Parasites Vectors. 2020;13(1):1-12. doi:10.1186/s13071-020-04302-z.

39. Pinkevych M, Petravic J, Bereczky S, Rooth I, Färnert A, Davenport MP, “Understanding the Relationship Between Plasmodium falciparum Growth Rate and Multiplicity of Infection," J. Infect. Dis., vol. 211, no. 7, pp. 1121-1127, Oct. 2014, doi: 10.1093/infdis/jiu561.

40. Makenga G, et al. Prevalence of malaria parasitaemia in school-aged children and pregnant women in endemic settings of sub-Saharan Africa: A systematic review and meta-analysis. Parasite Epidemiol Control. 2020;11:e00188. doi:10.1016/j.parepi.2020.e00188.

41. Smith DL, Drakeley CJ, Chiyaka C, Hay SI. "A quantitative analysis of transmission efficiency versus intensity for malaria," Nat Commun, 1, 8, 2010, doi:10.1038/ncomms1107.

42. Smith DL, Battle KE, Hay SI, Barker CM, Scott TW, McKenzie FE. "Ross, Macdonald, and a theory for the dynamics and control of mosquito-transmitted pathogens," PLoS Pathog, 8, 4, 2012, doi:10.1371/journal.ppat.1002588.

\section{Figures}




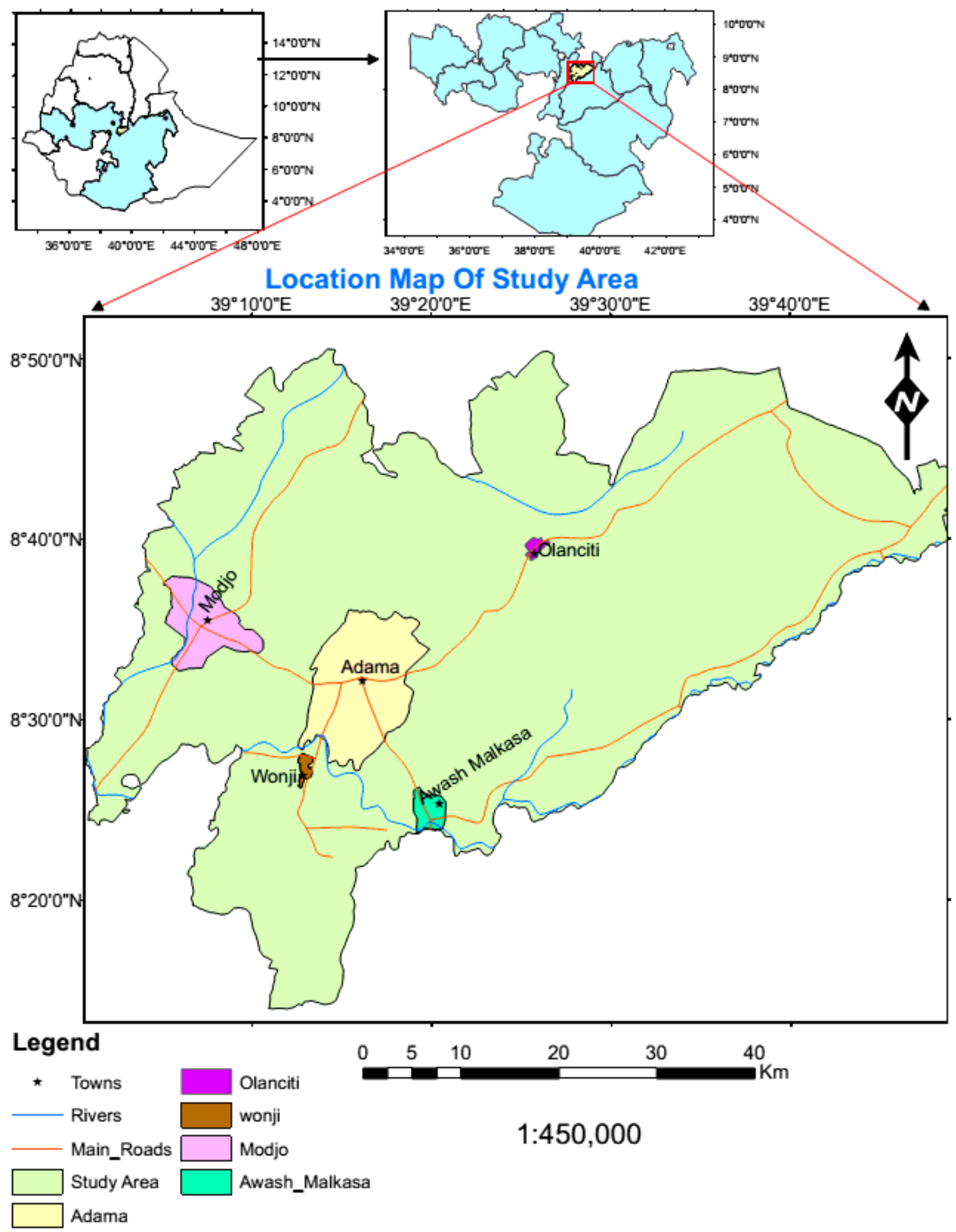

Figure 1

Map of the study area 


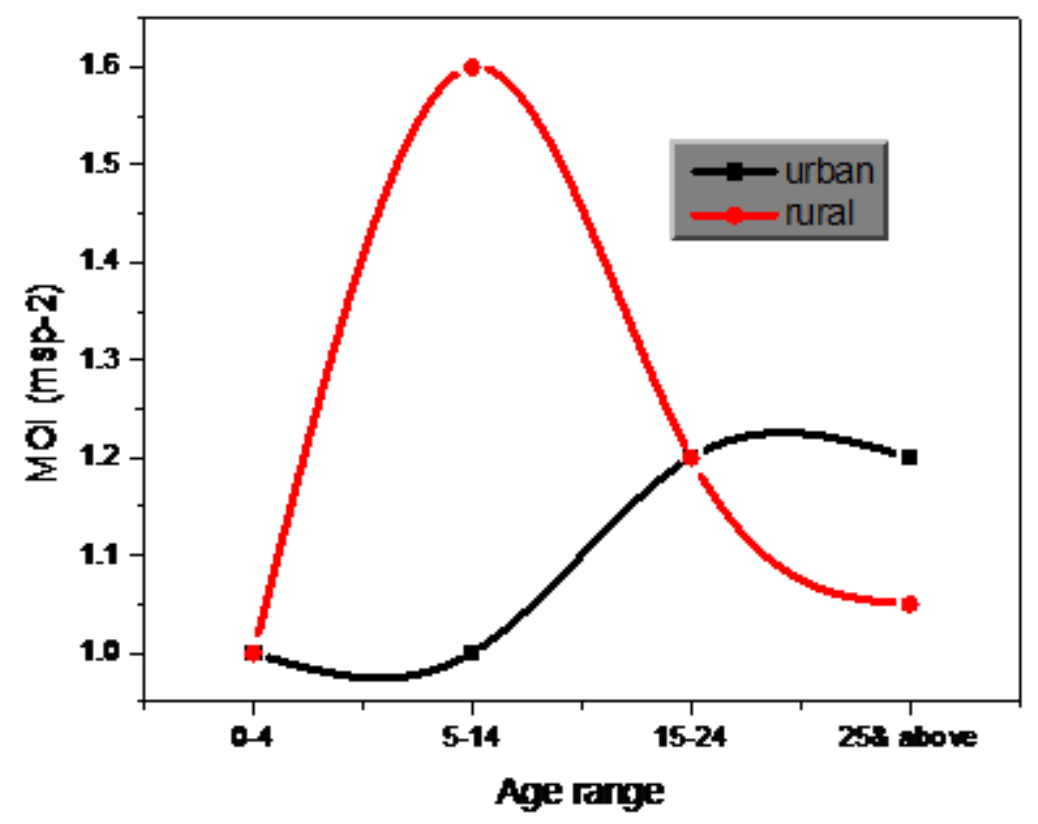

Figure 2

Urban rural features in $\mathrm{MOI}$ of P. falciparum msp-2 allelic families isolated from different age groups of symptomatic patients in Adama and its surroundings, Oromia, Ethiopia $(n=148)$.

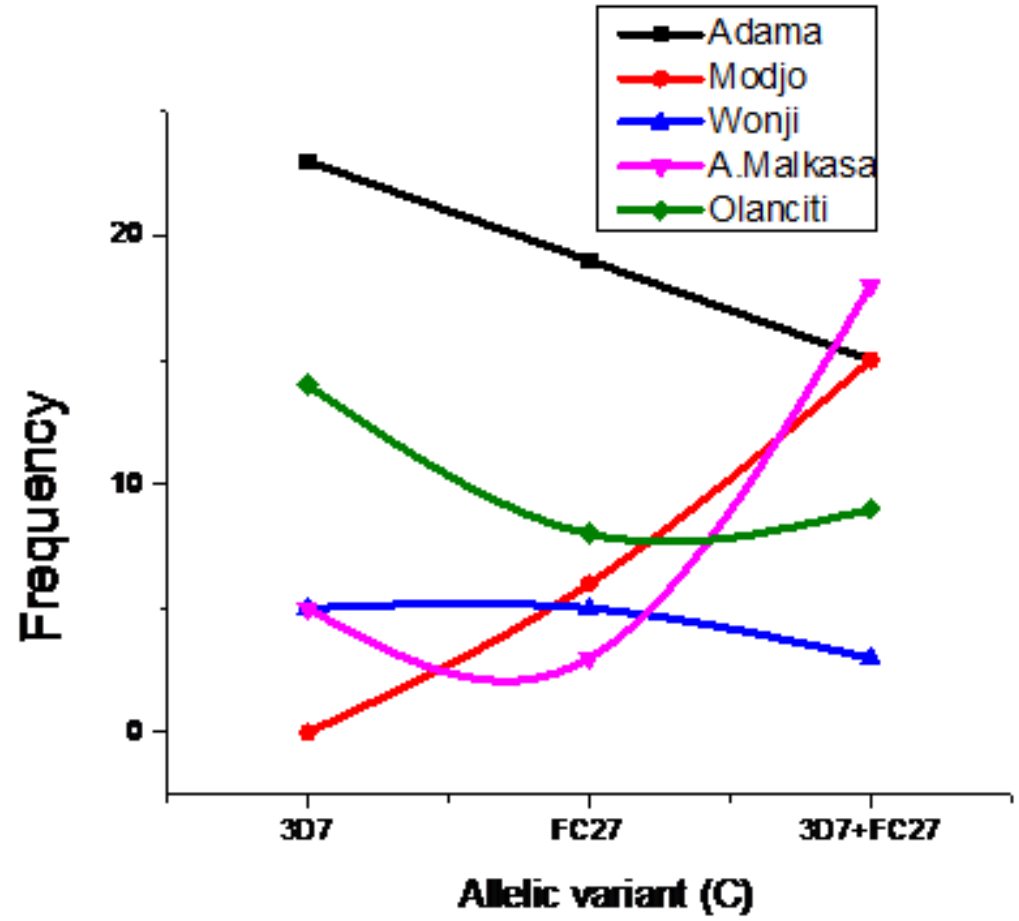

Figure 3

The distribution of P. falciparum msp-2 allelic families isolated from different sample collection sites Loading [MathJax]/jax/output/CommonHTML/jax.js s surroundings, Oromia, Ethiopia $(\mathrm{n}=148)$. 


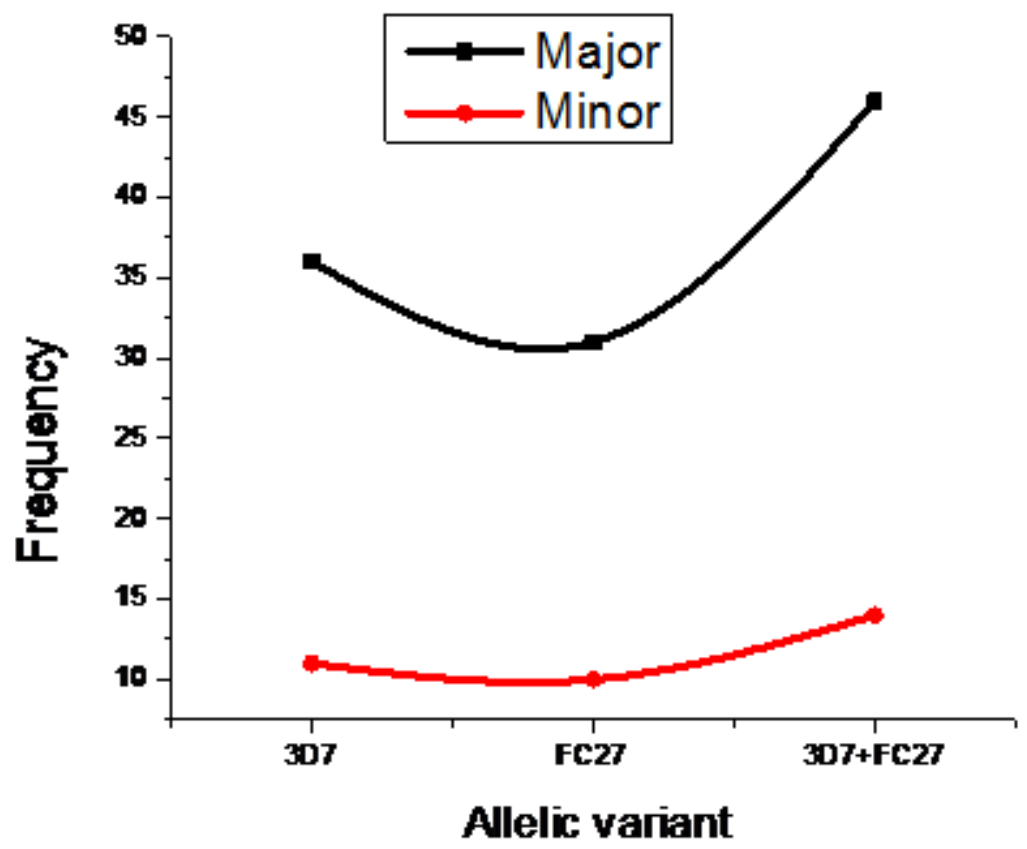

Figure 4

The distribution of P. falciparum msp-2 allelic families clinically isolated during major and minor malaria season from symptomatic patients in Adama and its surroundings, Oromia, Ethiopia $(n=148)$.

\section{Supplementary Files}

This is a list of supplementary files associated with this preprint. Click to download.

- S1Table.docx

- S2Figure.docx 